\title{
Article \\ Emotional Impact of Dishes versus Wines on Restaurant Diners: From Haute Cuisine Open Innovation
}

\author{
Ana Mengual-Recuerda ${ }^{1, *(\mathbb{D})}$, Victoria Tur-Viñes $\left.{ }^{2} \mathbb{(}\right)$, David Juárez-Varón ${ }^{3, * \mathbb{C}}$ and Faustino Alarcón-Valero ${ }^{1}$ \\ 1 Department of Business Organization, Universitat Politècnica de València, Valencia 46022, Spain; \\ faualva@omp.upv.es \\ 2 Department of Communication and Social Psychology, University of Alicante, Alicante 03690, Spain; \\ victoria.tur@ua.es \\ 3 Department of Mechanical and Materials Engineering, Universitat Politècnica de València, \\ Valencia 46022, Spain \\ * Correspondence: anmenre1@upv.es (A.M.-R.); djuarez@upv.es (D.J.-V.)
}

Citation: Mengual-Recuerda, A.; Tur-Viñes, V.; Juárez-Varón, D.; Alarcón-Valero, F. Emotional Impact of Dishes versus Wines on Restaurant Diners: From Haute Cuisine Open Innovation. J. Open Innov. Technol. Mark. Complex. 2021, 7, 96. https:// doi.org/10.3390/joitmc7010096

Received: 14 February 2021

Accepted: 13 March 2021

Published: 16 March 2021

Publisher's Note: MDPI stays neutral with regard to jurisdictional claims in published maps and institutional affiliations.

Copyright: (c) 2021 by the authors. Licensee MDPI, Basel, Switzerland. This article is an open access article distributed under the terms and conditions of the Creative Commons Attribution (CC BY) license (https:// creativecommons.org/licenses/by/ $4.0 /)$
Abstract: Haute cuisine is emblematic in the world of tourism and is of fundamental importance in the economic and social life in most countries worldwide. Haute cuisine gastronomic experiences play with the senses, involving the diner, thus generating a unique experience for the customer. This empirical study aims to analyze the influence on the consumer of the characteristic stimuli of a high-level gastronomic experience in a restaurant with two Michelin stars. Using neuromarketing biometrics, combined with a qualitative research technique, the objective of this research was to determine the emotional impact of the presentation and tasting of dishes compared to wines and to draw conclusions about each variable in the general experience. The results indicate that the dishes have a greater influence on the level of interest than the wines, and both have a different emotional impact at different moments of the experience due to its duration.

Keywords: haute cuisine; gastronomic experience; experiential marketing; neuromarketing; consumer behavior

\section{Introduction}

Innovation is a determining factor in the success of companies, insofar as it has become their most important engine of transformation and growth [1]. An organization cannot innovate in isolation [2], and has to engage with different types of partners to acquire ideas and resources from the environment, and thus be able to be competitive [3]. Open innovation is a paradigm that assumes that firms can and should use external ideas as well as internal ideas, and internal and external paths to market, as firms look to advance their technology. Chesbrough's definition is the most commonly used in the literature [2], being broad and underlining the emergence of valuable ideas from internal and external sources.

Open innovation allows companies to collaborate with external agents with the aim of finding better strategic solutions based on new ideas and processes [3]. Globalization and communications have given even more importance to open innovation as it is a process purposively managed, where knowledge flows across organizational boundaries using pecuniary and non-pecuniary mechanisms in line with the organization's business model [4]. There are three key trends in open innovation research: better measurement, resolving the role of appropriability, and linking that research to the management and economics literature [5].

One possible method of innovation is focused on improving business management based on technology, quality, new procedures, and forms of customer satisfaction [6]. This allows companies to increase their competitiveness, consequently helping them to grow [7]. Business competitiveness can increase when there is collaboration in $\mathrm{R}+\mathrm{D}$ 
(research and development). Open innovation is an ally of sustainability, generating new opportunities and challenges [8].

The service sector (third sector) represents a significant proportion of the economy in developed countries [9]. The globalization of many sectors, in which local agents previously predominated, has characterized the economic reality in recent years [10]. The globalization of services has manifested in a different way from that of manufactured goods, and competitiveness is the key to increasing profitability under the prevailing market conditions [11]. The future of the service economy depends on the recognition, dedication, and fostering of innovation around the world as a key component [12].

The Fourth Industrial Revolution facilitates the quantification of customer behavior and the understanding of design, which is key in the food and beverage business [13]. Therefore, supporting small restaurants to be successful must be based on open innovation applied to ingredients, recipes, and service [14]. Within the service sector, tourism represents an area of activity with its own clear identity and a segment of fundamental importance in the economic and social life of most countries in the world [15]. The ability to potentially absorb new knowledge in tourism companies positively influences the results of innovation in marketing [16]. One of the market trends within the tourism sector is gastronomic tourism, which is considered to be an emerging sector, where culture and gastronomy are part of the same journey.

The restaurant sector is key in the cultural economy of a country [17] as they have to adapt to changes in consumer habits while being influenced by new experiences or technological changes [18]. Culinary creativity, restaurant decoration, quality of service, or technological level are key to innovation in a sector whose challenge is to offer a memorable experience [19]. There are models that relate innovation in a restaurant to the brand, perceived quality, and customer loyalty [20]. Open innovation is essential for the success of restaurants, generating new business lines related to ingredients or independent services. Competition fosters product innovation in restaurant companies, but investment in Information and Communications Technology (ICT) and in staff training has been shown to be the main determinants of product and process innovation in the restaurant industry [21]. Creativity and innovation in the gastronomy sector have become increasingly relevant determinants of success, business performance, and longer-term survival [22]. The implementation of technology in the tables of a restaurant can increase sales per minute or its productivity by approximately $11 \%$ [23]. Artificial intelligence (AI), mobile apps, kiosks, and chatbots are revolutionizing the consumer experience and facilitating the automation of restaurant operations [24].

Haute cuisine has changed and is evolving toward a new design and use of aromas, considering the customer as a co-creator of value for the restaurant [25]. Haute cuisine is a tourist emblem for large cities worldwide, and is fast becoming a tourist attraction in the U.S., Europe, and Japan, where the main objective of haute cuisine is to excite the consumer through the dining experience [26]. This type of gastronomy plays with the five senses, involving the diner and transmitting aromas, visual effects, and colors as an integral element that generates a unique experience for the customer [27] as well as using experiential and sensory marketing to surprise and retain the customer [28].

Open innovation in gourmet restaurants proposes that customers should be seen as co-creators of the value of haute cuisine [25]. Innovation in haute cuisine restaurants contributes to stimulating the creation and development of gastronomy tourism products through innovation processes that add quality to the products and services offered by gastronomy tourism [29].

A world benchmark indicator of innovation in the gastronomic sector is the Michelin guide [30], whose evaluation of restaurants is given using stars. This guide originally contributed to better mobility, and is today an assessment of haute cuisine restaurants, with 204 restaurants awarded in the world in 2020 [31]. Spain is a leading destination in the sector, and is among the best positioned countries according to most "best restaurants in the world" guides [32]. The restaurant sector in Spain has given way to more professional 
models, differentiating itself by a unique customer experience, the key in experiential marketing, by taking into account that culture, nature, and gastronomy are the main motives when choosing a tourist destination.

The consumer needs and habits of people have changed over the last twenty years [33]. The growing relevance of the "novelty" factor [34], combined with innovation [35], design, and product life cycle, has led the transformation of the competitive situation [36]. There is currently growing interest in research about "consumer neurosciences" [37], which analyzes the influence of perceptual characteristics measured using neurophysiological tools [38]. This allows market research through the analysis of consumer responses to brand stimuli [39], understanding how the brain works [40], how we interpret the world we live in [41], and more importantly, how we interact and the way we make decisions [42]. One of the outstanding innovations in the food sector is the performance of studies using neuromarketing technology [43], which focuses on the perception and marketing of food [44], the evaluation of the information presented in the labeling [45], the detection of preferences in the consumption of brands or organic products [46], or the taste-brand correlation and the influence of ambient light in the choice of healthy foods [47]. Biometrics used in neuromarketing are becoming more economical, providing low-cost equipment with equivalent performance to major brands now available in universities and research centers, so that access to this equipment is easier. Finally, the scientific literature is becoming wider, allowing easier access to the methodology and its application.

\section{Materials and Methods}

The main objective of the present research work was to analyze cognitive perception using neuromarketing biometrics to register and analyze the brain's response to the presentation and tasting of food and beverages in a haute cuisine restaurant. It is based on the mixed construct type "experience" of consumers who like to live a haute cuisine gastronomic experience. These consumers have a medium-high socioeconomic level and are between 35 and 55 years old. The experience is centered on the food, the drink, the moment it is served, and the presentation. The factors that remain constant are the restaurant, the atmosphere, the table, and the menu.

With this objective in mind, we used neuromarketing biometrics to analyze the galvanic skin response (emotional intensity or arousal) experienced according to the subjects' attention to the stimuli (eye tracking) and the interpretation of the emotions experienced (electroencephalography). The authors developed this research using neuromarketing technology to analyze the emotional impact of the stimuli generated and identify the most significant aspects.

The experience was carried out repeatedly in groups of four diners, always at the same table, and attended to by the same professionals. Each diner was monitored with biometrics that recorded the emotional impact of the programmed stimuli (tasting menu of 18 dishes) and averaged the behavior of the group for each of them.

\subsection{Objectives}

This empirical research work was to identify the most relevant aspects for consumers who experience haute cuisine gastronomic services.

The experiential project was conducted in the restaurant L'Escaleta, located in Alicante (Spain), and has two Michelin stars. It is a restaurant that aims to bring innovation to traditional flavors and whose chef, Kiko Moya, seeks to create his own identity without relying exclusively on reconstruction.

The main objective of this empirical research was to record and analyze the brain response to the stimuli of "presentation" and "tasting" of food and beverages in a haute cuisine restaurant, based on the mixed construct type "experience".

The relevance of this main objective was to learn the consumer's focus of attention, highlighting the aspects they valued the most or made their experience more special, and to create new opportunities to improve excellent gastronomic experiences based on 
improved stimuli. This will allow an analysis of whether the perception of the experience (arousal value recorded) can be assigned to the presentation or tasting phase, based on neuromarketing biometric records. Similarly, we also aimed to discover the possible need for the consumer to have prior experience or knowledge of certain stimuli.

Based on this main objective, secondary objectives were proposed such as the analysis of the influence of the duration of the experience on the emotional perception of consumers, both at the level of emotional intensity as well as the analysis of related emotions and the evolution of the levels reached.

\subsection{Research Instrument}

Neuromarketing analyzes the effectiveness of the stimuli created by the brand [32] and consumer behavior from the psychological perspective [48], combining neuroscience, psychology, and economics [49]. This discipline improves on traditional market research methods, limited by consumer behavior (their perceptions) [50,51].

Emotions have great relevance in the decision-making process [48,52]. Emotion and reason are two complementary mechanisms in the decision-making process that takes place in the brain $[53,54]$.

Neuromarketing tries to promote the connection of neuronal activity and consumer behavior (neurosciences applied to economics) $[55,56]$ to understand the behavior and needs of customers $[57,58]$.

Consumers seek experiences in different settings such as in restaurants and thus we have the emerging "culture of experience" [59]. Sensory marketing manages the communication of the brand toward the senses [60], analyzing the perception and behavior of consumers [61] as a complement to rational marketing [62]. "Sensory pleasure" appeals to the client's senses, creating unforgettable experiences [19,63], facilitating the client's reaction to emotional and creative stimulation, and is connected to certain lifestyles [64].

The human brain regulates the level of the emotion, reaching balance and tranquility (concept of emotional evanescence) after a greater or lesser period of time. Consequently, extraordinary things become ordinary after repeating the experience or after a time [65]. It is a balance of the organism at the psychological level [66], which occurs with body temperature or sleep $[67,68]$ (homeostatic balance).

Previous neuromarketing studies have been applied to the food sector that have focused on the better performance of food perception and marketing [44], the presence of additives and information evaluation (label content) [69], or detecting preferences in the consumption of organic brands or products [70].

Marketing specialists have the opportunity to study information related to packaging, promotions, etc., and their corresponding decision-making, based on changes in brain activity [71], thanks to techniques such as functional magnetic resonance imaging (neuroimaging techniques).

Cognitive options and emotional options, regarding the design of typical products and consumer behavior (in relation to their purchase), are explored by neuromarketing to verify their efficiency [72]. There is a direct relationship between the amount of information available to the consumer and the taste of the chosen products [73] as well as the tastebrand correlation and the influence of ambient light on healthy food choices [47].

The techniques used in this work (neuromarketing techniques) were eye tracking (ET), galvanic skin response (GSR), and electroencephalography (EEG). Eye tracking records the subjects' attention to a stimulus, leading to cognitive and affective processing (partially recorded by GSR and EEG), and influencing consumer preferences [74-76].

Recording activities were naturally followed by studies of synchronized pupil trajectory (gaze fixation), galvanic skin response, and emotional levels (using electroencephalography) to register emotional traces or somatic markers in each phase and at the general experience level, according to the levels of the biometrics recorded [19].

Subsequently, the perception of value from the presentation and tasting experiences (based on the percentage value of the emotion register) were measured and differenti- 
ated, recording the greatest interest stimuli for the consumer and the level of emotional arousal [77].

\subsection{Sample}

In this research, the sample consisted of a total group of 30 people (balanced in gender), according to the restaurant consumer target. All of them met the requirements of medium-high socioeconomic level and aged between 35 and 55 .

The field work was carried out between January 2018 and February 2019. The measurement of the subjects was carried out at an isolated table, called the "zero table", of the L'Escaleta restaurant. The sample size (15 men and 15 women) selected was mainly conditioned by the neuromarketing techniques used. The final size corresponded to the largest required by the techniques used, as indicated by the providers (minimum 8-9 people for EEG [78], 30 people for GSR [79], and 4-5 people for ET [80]. This is in accordance with a prestigious neuromarketing study [81] and was structured in one phase.

\subsection{Data Collection and Analysis}

The elaboration of the eye-tracking model for the research phase of dishes and drinks was performed using "Pupil Core" biometry (Pupil Labs manufacturer-200 Hz sampling frequency). The data collection was carried out using Pupil Capture Software, 1.23 version. To record the electrodermal activity in the same phase, the galvanic skin response equipment Shimmer3 GSR+ was used, using, for data collection, the ConsensysPRO software, v.1.6. Changes in brain wave electrical currents recording was carried out using the EEG "EPOC+" model equipment with 14 channels (manufacturer Emotiv-saline-based electrodes). Data collection was carried out using the EmotivPRO v.2.0 software. Finally, the data statistical analysis used R software, v.3.6.3.

The subjects were exposed to common elements (stimuli) with 18 dishes and 10 wines organized in 11 starters or snacks, with three wines, four main courses; with four wines, and three desserts; and with three wines (Figure 1 and Table 1) for all diners (volunteers). Subjects were instructed not to eat or drink while the dishes or wines were presented to them, before proceeding to divide presentation and tasting of each stimulus to identify which generated the most interest [82].

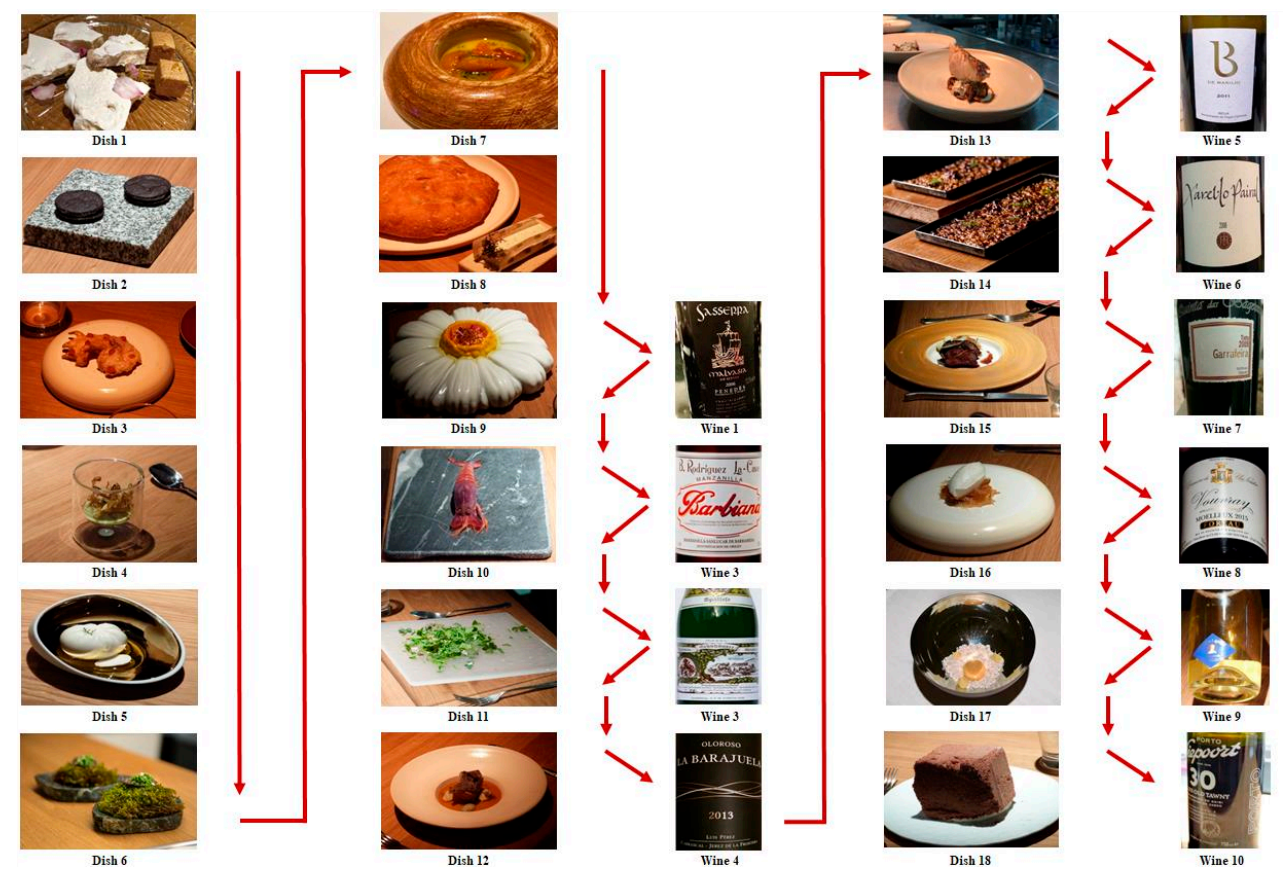

Figure 1. Stimulus (dishes and wines) and order established by the chef and sommelier. Source: Prepared by the authors. 
Table 1. Stimulus description. Source: Original work from the authors.

\begin{tabular}{|c|c|c|c|}
\hline Moment & Dish $n^{\circ}$ & Description & Abbreviation \\
\hline \multirow{14}{*}{ Snacks and starters } & Dish 1 & $\begin{array}{l}\text { Alicante savory nougat/turron (Turrón salado } \\
\text { Alicante y Jijona) }\end{array}$ & Turrón \\
\hline & Dish 2 & Oreo de ajo (Black and White Garlic Oreo) & B\&W Oreo \\
\hline & Dish 3 & Chicharrón de pollo (Chicken cracklings and egg yolk) & Chicharrón \\
\hline & Dish 4 & Hummus de alcachofas (Artichoke hummus) & Hummus \\
\hline & Dish 5 & Queso fresco de almendras (Fresh almond cheese) & Queso \\
\hline & Dish 6 & Musgo (Moss) & Musgo \\
\hline & Dish 7 & Erizos (Pumpkin hedgehogs) & Erizos \\
\hline & Dish 8 & $\begin{array}{l}\text { Pan con mantequilla de hierbas (Sourdough bread } \\
\text { with regional herb butter) }\end{array}$ & Pan \\
\hline & Dish 9 & $\begin{array}{l}\text { Sabayón de azafrán con polen fresco y flores (Saffron } \\
\text { sabayon with fresh pollen and flowers) }\end{array}$ & Polen \\
\hline & Wine 1 & Vega de Ribes Saserra 2006. Penedés & Malvasía \\
\hline & Dish 10 & Gamba roja (Salted red shrimp) & Gamba \\
\hline & Wine 2 & $\begin{array}{l}\text { Delgado Zuleta Rodríguez La-Cave } \\
\text { Barbiana. SanLúcar }\end{array}$ & Manzanilla \\
\hline & Dish 11 & $\begin{array}{l}\text { Crema de mostaza salvaje con hierbas recién cortadas } \\
\text { (Wild mustard cream with freshly cut herbs) }\end{array}$ & Mostaza \\
\hline & Wine 3 & $\begin{array}{l}\text { Maximin Grünhaus Abtsberg Riesling Spätlese } \\
\text { 2009. Ruwer }\end{array}$ & Blanco Alemán \\
\hline \multirow{8}{*}{ Main courses } & Dish 12 & $\begin{array}{l}\text { Blanquet (White sausage with butterbean and } \\
\text { black truffle) }\end{array}$ & Blanquet \\
\hline & Wine 4 & Luis Pérez La Barrajuela Oloroso 2013. Jerez & Jerez \\
\hline & Dish 13 & $\begin{array}{l}\text { Mero con setas (Grilled grouper with mushrooms and } \\
\text { hazelnut butter dressing) }\end{array}$ & Mero \\
\hline & Wine 5 & Basilio Izquierdo B de Basilio 2011. Rioja & Rioja Blanco \\
\hline & Dish 14 & $\begin{array}{l}\text { Arroz al cuadrado (Dry cuttlefish rice with broad } \\
\text { beans and artichokes) }\end{array}$ & Arroz \\
\hline & Wine 6 & Can Ràfols dels Xarel·lo Pairal 2006. Penedés & Penedés \\
\hline & Dish 15 & $\begin{array}{l}\text { Tira de asado (Strip of roast lamb lacquered in its } \\
\text { juices with grilled aubergines) }\end{array}$ & Asado \\
\hline & Wine 7 & Quinta des Bágeiras Garrafeira 2009. Bairrada & Bairrada \\
\hline \multirow{6}{*}{ Desserts } & Dish 16 & $\begin{array}{l}\text { Helado de chirivía con cabello de ángel (Parsnip ice } \\
\text { cream with pumpkin cream and muscat vinegar) }\end{array}$ & Chirivía \\
\hline & Wine 8 & Domaine du Clos Naudin Moelleux 2015. Loira & Dulce Francés \\
\hline & Dish 17 & Espíritu de un brioche (Spirit of a Brioche) & Brioche \\
\hline & Wine 9 & $\begin{array}{l}\text { Gutiérrez de la Vega Furtiva Lágrima Cavatina } \\
\text { 2012. Alicante }\end{array}$ & Moscatel dulce \\
\hline & Dish 18 & Supermousse (Chocolate with coffee and hazelnut) & Supermousse \\
\hline & Wine 10 & Neipoort 30 Years Old Tawny. Porto & Oporto \\
\hline
\end{tabular}

Age and sex (identified by the restaurant, and with a similar sociocultural profile) were the independent variables. The peaks of excitement, the focus of attention, and the brain activity levels, before the projected stimuli, were the dependent variables.

Dishes $5,6,9,10,11,14,16$, and 17 were served on special plates. However, all wines were served in standard glasses.

Dishes and wines were served according to the chef and sommelier's proposal, and biometrics were collected to identify the dishes and wines with the important emotional impact on consumers (Figure 2). Visual attention (eye tracking), level of emotional arousal (electrodermal activity), and brain activity (based on data collected by electroencephalography) were recorded. 


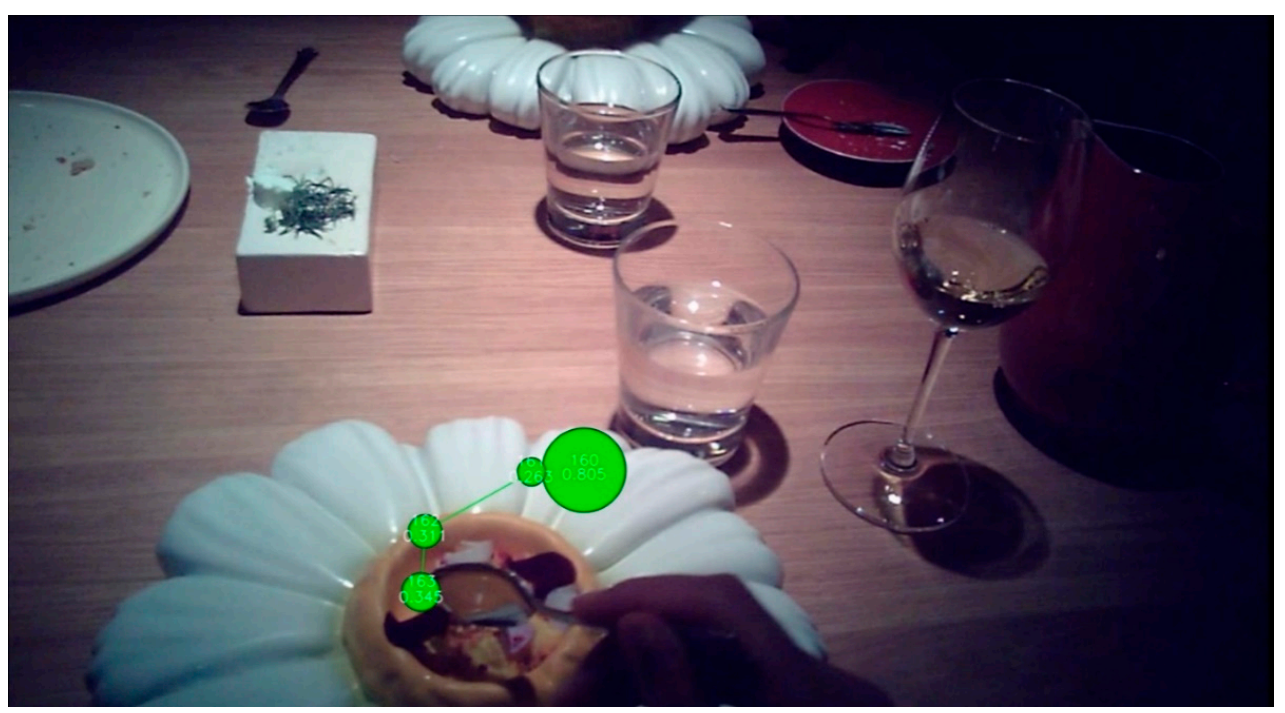

Figure 2. Neuromarketing empirical study. Source: Original work from the authors.

The in-depth interview (semi-structured interview protocol), which took place after the tasting experience, was carried out to provide further evidence. All interviews were "face-to-face" and carried out by the authors (videotaped). A transcription was prepared for subsequent analysis.

\section{Results}

\section{Arousal Analysis for Each Dish and Wine (Presentation and Tasting Phases)}

Figures 3-5 show the arousal level for the presentation phase and the tasting phase for each dish and wine, separated by the three groups of the menu: starters, main courses, and desserts.

The galvanic skin response (GSR) average experience was 0.47 (parts per unit). All GSR values referenced to the gastronomic experience average.

In the first group (Starters), dishes such as hummus, pollen, prawn or mustard (references $4,7,9$, and 11) showed a GSR value for presentation below the average, increasing considerably, however, during tasting. This indicates that the emotional intensity of the presentation of the dish was lower than that of the tasting.

Only the dishes Turrón, Oreo, Chicharrón, Queso, Musgo, and Pan (references 1, 2, 3, 5,6 , and 8 , respectively) showed a level of arousal of the presentation that was higher than the tasting.

Wines in this group (Malvasía and Blanco Alemán) showed a higher level of arousal in presentation than in tasting.

The average for dish presentation (0.53) was equal to dish tasting (0.53) in this group. However, the average for wine presentation (0.63) was higher than the wine tasting $(0.37)$, and superior to the dish values.

In this group (Main Courses), most of the dishes had GSR values (presentation and tasting) below the experience average. Only the Blanquet dish had values over the experience average, and moreover, tasting was higher than presentation. For the main courses, the arousal of the presentation and tasting was lower than the experience average. This was due to the experience length, as most of the dishes were served after the mid-point of the experience, and consumer attention decreased.

There were four wines in this group. Wines Jerez, Rioja Blanco, and Bairrada showed a higher level of arousal in presentation than in tasting. Only the Penedés wine showed a higher level of arousal in tasting than in presentation. All of them showed values in tasting below the experience average. 


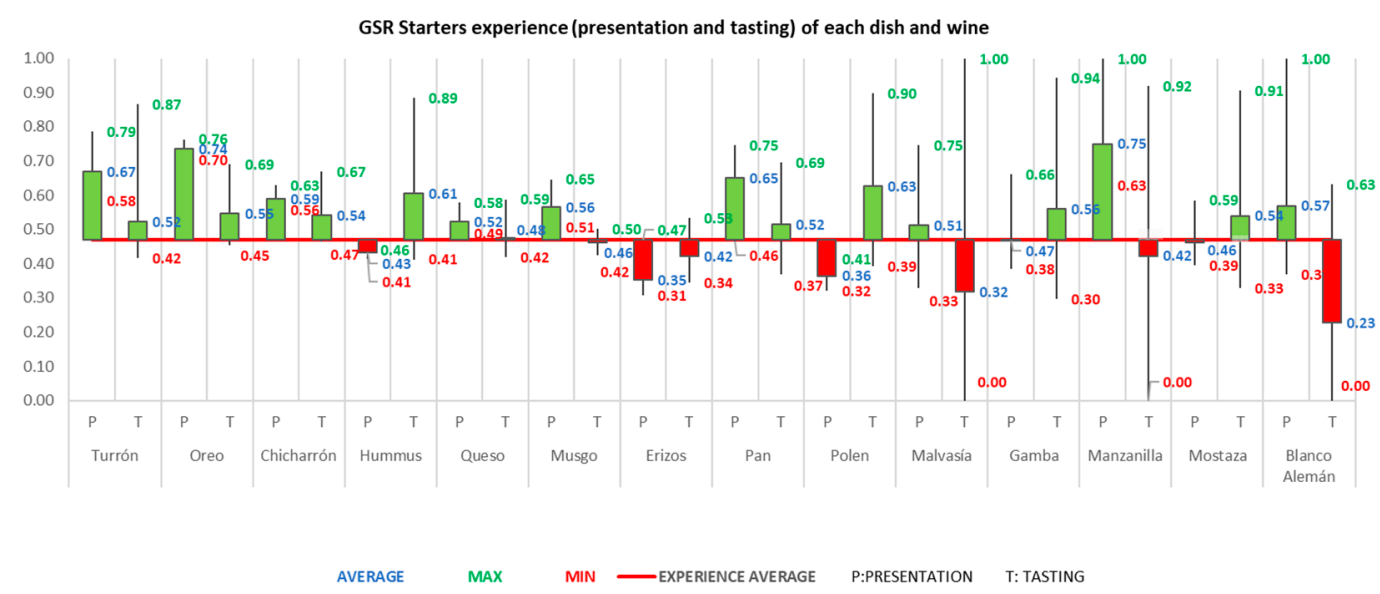

Figure 3. Galvanic skin response analysis for each dish and wine (presentation and tasting): Starters group. Source: Original work from the authors.

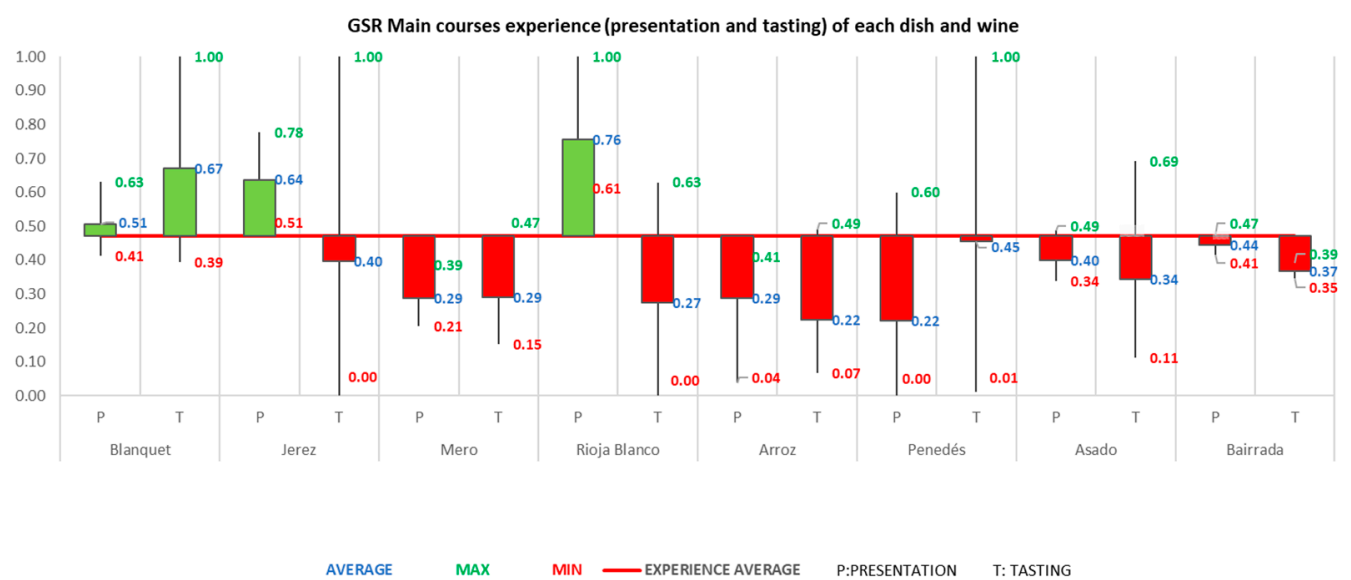

Figure 4. Galvanic skin response analysis for each dish and wine (presentation and tasting): Main courses group. Source: Original work from the authors.

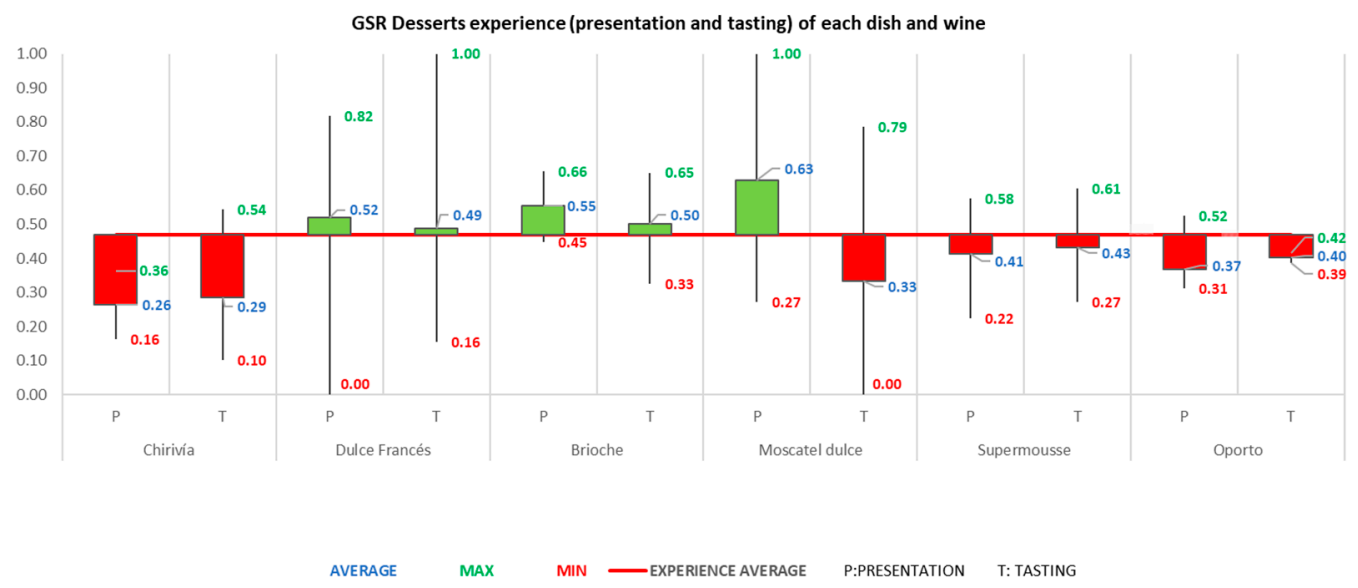

Figure 5. Galvanic skin response (GSR) analysis for each dish and wine (presentation and tasting): Desserts group. Source: Original work from the authors.

The average for dish presentation (0.37) was similar to tasting (0.38) in this group. However, the average for wines presentation (0.51) was higher than wine tasting (0.37), and superior to the values of the dishes. 
In this group (Desserts), the dishes Chirivía and Supermousse had GSR values (presentation and tasting) below the experience average. In both cases, presentation was lower than tasting. Only the Brioche dish had values over the experience average, and presentation was higher than tasting. The arousal of the presentation and tasting was lower than the experience average.

There are three wines in this group. Dulce Francés and Moscatel Dulce wines showed a higher level of arousal in presentation than in tasting. Only Oporto wine showed a higher level of emotional intensity in tasting than in presentation, but both were below the experience average.

The average for dish presentation (0.41) was equal to tasting (0.41) in this group. However, the average for wine presentation (0.41) was lower than wine tasting (0.51), which was superior to the dishes' tasting values. In this group, it was significant that the wines were sweet.

Figure 6 shows the global value of the arousal for each dish and wine:

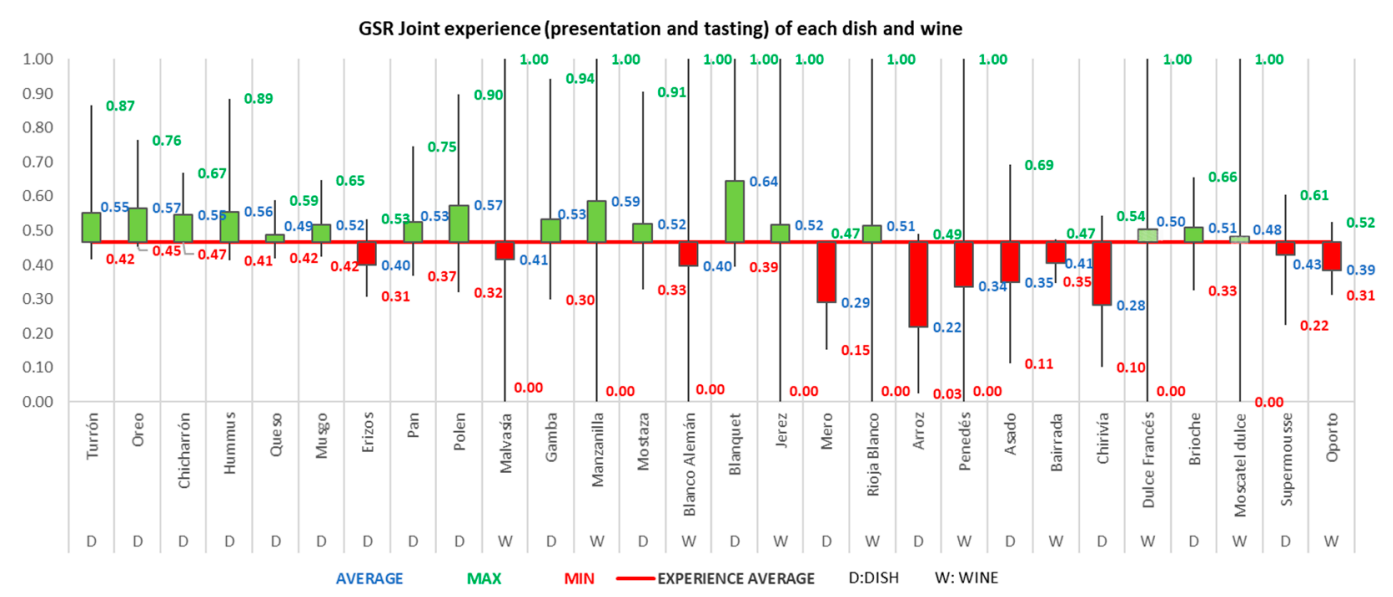

Figure 6. GSR joint analysis of presentation and tasting for each dish and wine. Source: Original work from the authors.

Arousal values are indicated with respect to the galvanic skin response average experience. Arroz, Mero, Chirivía, Asado, Erizos, and Supermousse were the dishes with the lowest arousal (above experience average value-in order). Blanquet, Oreo, Polen, Hummus, Turrón, Chicharrón, Pan, Gambón, Musgo, Mostaza Brioche, and Queso were the dishes with the highest arousal (below average value-in order).

The wines with the best record of emotional intensity were (above experience average value-in order): Manzanilla, Jerez, Rioja Blanco, Dulce Francés, and Moscatel Dulce. Wines with the lowest register of arousal were (below average value-in order): Penedés, Oporto, Blanco Alemán, Malvasía, and Bairrada.

Figure 7 shows the level of arousal divided into three groups, corresponding to the chef's proposal of Starters, Main Courses, and Desserts. The average galvanic skin response data of each dish and each wine, for the presentation phase and tasting phase, are included together with the dish average and wine average. According to the menu designed by the chef and the sommelier, the level of arousal (compared by groups of dishes and wines) of the experience showed that differences between these moments were significant, with the Starters the better rated (with an average GSR of 0.53 for dishes, 0.47 for wines and 0.51 for the starters group experience), followed by Desserts ( $0.41,0.46$ and 0.43 , respectively) and Main Courses (0.38, 0.44 and 0.41 , respectively). In group 1 (Starters), the GSR average for wines was lower than the GSR average for dishes, but during groups 2 (Main Courses) and 3 (Desserts), the wine GSR average was higher than the dish average. Group 1's GSR average experience was $21.43 \%$ higher than the GSR average experience of groups 2 and 3. The midway point of the experience was between the Gamba and Mostaza dishes, so Main Courses and Desserts were in the second part of the experience. In this second part was when the wines' GSR average was higher than the dish GSR average. Fatigue on the part of 
the consumers is a possible partial conclusion and occurs after the midway point (moment from which the main dishes and desserts arrive) of the experience.

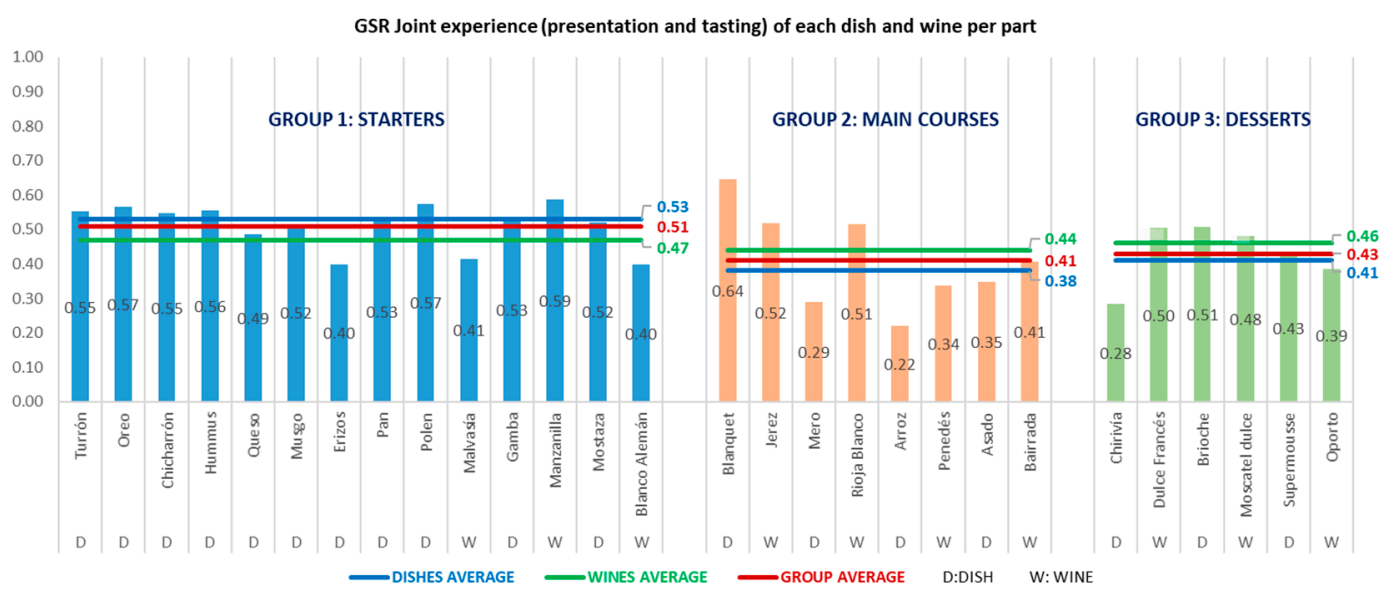

Figure 7. Presentation and tasting global GSR analysis for each dish and wine. Groups for the three phases. Source: Original work from the authors.

The duration (average of $2 \mathrm{~h}$ and $32 \mathrm{~min}$ ) of the experience can be summarized, globally, in the levels of arousal of the dishes and wines, separated by presentation and tasting. Figure 8 shows the galvanic skin response average data for the presentation phase and tasting phase of the dishes and wines:

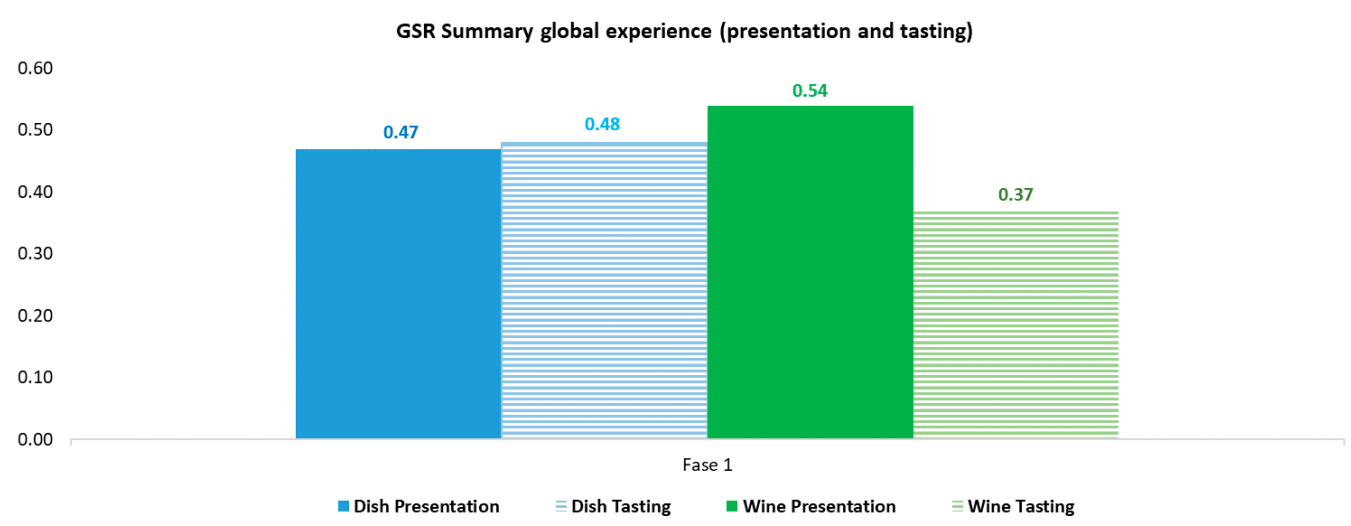

Figure 8. GSR summary analysis of presentation phase and tasting phase for dishes and wines. Source: Original work from the authors.

Table 2 shows a summary of the quantitative results for GSR global measurement.

There were significant differences in emotional intensity between the Starters group and the Main Courses and Desserts groups. This was due to the duration of the experience.

The emotional intensity of the Starters group was $24 \%$ higher than the Main Courses group and 19\% higher than the Desserts group. The level of emotional intensity generated by the dishes was 39\% higher in the Starters group than in the Main Courses group, and $29 \%$ higher than in the Desserts group.

The level of emotional intensity generated by the wines was 7\% higher in the group of Starters than in the group of Main Courses, and 2\% higher than in the Desserts group.

Differentiating between dishes and wines, the dishes had 13\% more emotional intensity (arousal) than the wines in the Starters group. However, the dishes had 14\% less emotional intensity in the Main Courses group, and 11\% less than the Desserts group. The 18-plates and 10-wines experience reduced the interest in the dishes (increasing interest in wines) as it progressed through the sequence. 
Table 2. GSR quantitative results summary for GSR. Source: Prepared by the authors.

\begin{tabular}{|c|c|c|c|c|c|c|}
\hline \multirow[b]{2}{*}{ Moment } & \multirow[b]{2}{*}{$\operatorname{Dish}^{\mathbf{o}}$} & \multirow[b]{2}{*}{ Abbreviation } & \multicolumn{4}{|c|}{ Arousal (Parts per Unit) } \\
\hline & & & $\begin{array}{c}\text { Joint } \\
\text { Experience }\end{array}$ & $\begin{array}{c}\text { Dishes } \\
\text { Average }\end{array}$ & Wines Average & Group Average \\
\hline \multirow{14}{*}{$\begin{array}{l}\text { SNACKS AND } \\
\text { STARTERS }\end{array}$} & Dish 1 & Turrón & 0.55 & \multirow{14}{*}{0.53} & \multirow{14}{*}{0.47} & \multirow{14}{*}{0.51} \\
\hline & Dish 2 & Oreo & 0.57 & & & \\
\hline & Dish 3 & Chicharrón & 0.55 & & & \\
\hline & Dish 4 & Hummus & 0.56 & & & \\
\hline & Dish 5 & Queso & 0.49 & & & \\
\hline & Dish 6 & Musgo & 0.52 & & & \\
\hline & Dish 7 & Erizos & 0.40 & & & \\
\hline & Dish 8 & Pan & 0.53 & & & \\
\hline & Dish 9 & Polen & 0.57 & & & \\
\hline & Wine 1 & Malvasía & 0.41 & & & \\
\hline & Dish 10 & Gamba & 0.53 & & & \\
\hline & Wine 2 & Manzanilla & 0.59 & & & \\
\hline & Dish 11 & Mostaza & 0.52 & & & \\
\hline & Wine 3 & Blanco Alemán & 0.40 & & & \\
\hline \multirow{8}{*}{$\begin{array}{c}\text { MAIN } \\
\text { COURSES }\end{array}$} & Dish 12 & Blanquet & 0.64 & \multirow{8}{*}{0.38} & \multirow{8}{*}{0.44} & \multirow{8}{*}{0.41} \\
\hline & Wine 4 & Jerez & 0.52 & & & \\
\hline & Dish 13 & Mero & 0.29 & & & \\
\hline & Wine 5 & Rioja Blanco & 0.51 & & & \\
\hline & Dish 14 & Arroz & 0.22 & & & \\
\hline & Wine 6 & Penedés & 0.34 & & & \\
\hline & Dish 15 & Asado & 0.35 & & & \\
\hline & Wine 7 & Bairrada & 0.41 & & & \\
\hline \multirow{10}{*}{ DESSERTS } & Dish 16 & Chirivía & 0.28 & \multirow{6}{*}{0.41} & \multirow{6}{*}{0.46} & \multirow{6}{*}{0.43} \\
\hline & Wine 8 & Dulce Francés & 0.50 & & & \\
\hline & Dish 17 & Brioche & 0.51 & & & \\
\hline & Wine 9 & Moscatel dulce & 0.48 & & & \\
\hline & Dish 18 & Supermousse & 0.43 & & & \\
\hline & Wine 10 & Oporto & 0.39 & & & \\
\hline & & & \multirow{4}{*}{\multicolumn{3}{|c|}{$\begin{array}{l}\text { Global experience of dish presentation } \\
\text { Global experience of dish tasting } \\
\text { Global experience of wine presentation } \\
\text { Global experience of wine tasting }\end{array}$}} & 0.47 \\
\hline & & & & & & 0.48 \\
\hline & & & & & & 0.54 \\
\hline & & & & & & 0.37 \\
\hline
\end{tabular}

Similarly, there was a significant difference between the level of arousal of the presentation and tasting of dishes, together with the presentation of wines, and the tasting of wines, mainly due to the protagonism of the dishes in the experience.

The GSR average values of the presentation phase and tasting phase of the dishes were similar, with the tasting slightly higher. However, the GSR average value of the wine presentation was $46 \%$ higher than the GSR average value of the tasting. In general, the average presentation and tasting of dishes (0.48) was higher than the average of the presentation and tasting of wines (0.46), but the highest average GSR register corresponded to the presentation of wines (0.54) and the lowest average register of GSR corresponded to wine tasting (0.37).

Figure 9 shows the GSR average percentage of each dish and wine, and every interpretation value obtained for the brain activity using EEG technology (Table 3). 


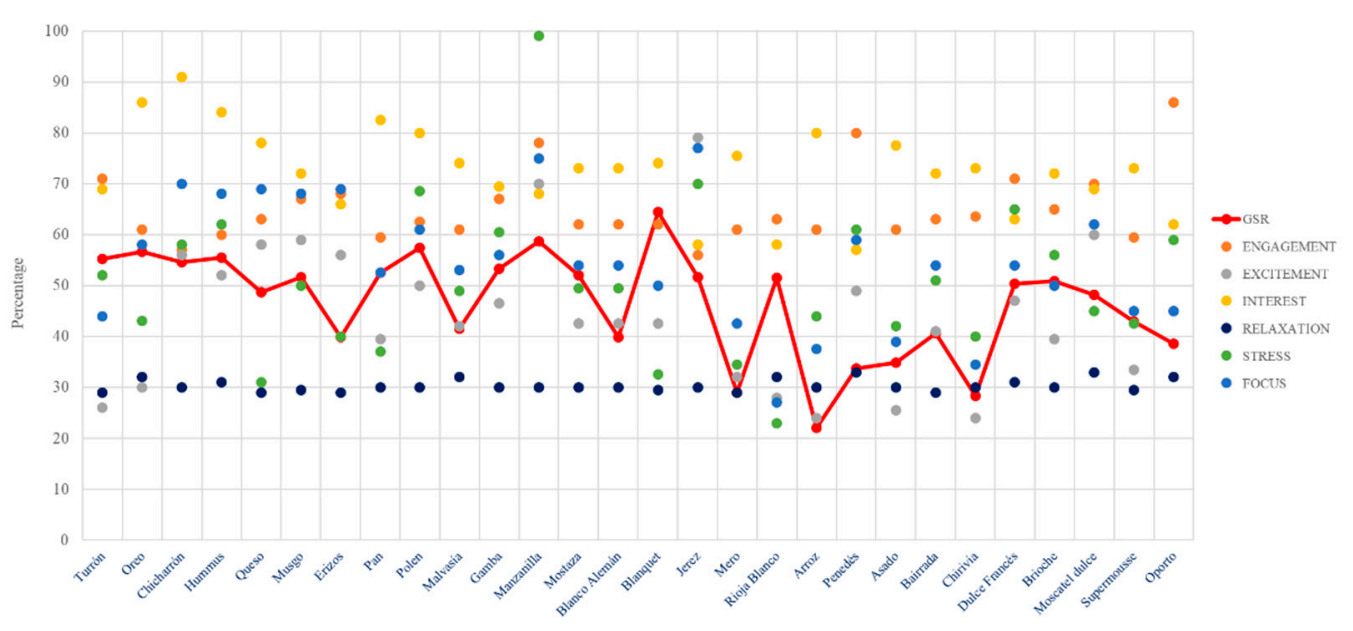

Figure 9. GSR and electroencephalography (EEG) summary analysis of presentation phase and tasting phase for each dish and wine. Source: Original work from the authors.

Table 3. GSR and electroencephalography (EEG) activity percentage (standard error). Source: Original work from the authors.

\begin{tabular}{|c|c|c|c|c|c|c|c|c|c|c|c|c|c|c|}
\hline \multirow{2}{*}{$\begin{array}{l}\text { Dish/Wine } \\
\text { Turrón }\end{array}$} & \multicolumn{2}{|c|}{ GSR } & \multicolumn{2}{|c|}{ Engagement } & \multicolumn{2}{|c|}{ Excitement } & \multicolumn{2}{|c|}{ Interest } & \multicolumn{2}{|c|}{ Relaxation } & \multicolumn{2}{|c|}{ Stress } & \multicolumn{2}{|c|}{ Focus } \\
\hline & 55.2 & $(1.2)$ & 71.1 & $(4.8)$ & 26.1 & $(1.5)$ & 69.1 & $(4.2)$ & 29.1 & $(1.1)$ & 52.1 & (1.5) & 44.1 & $(0.8)$ \\
\hline Oreo & 56.6 & (5.8) & 61.1 & (3.7) & 30.1 & $(0.8)$ & 86.1 & (2.9) & 32.1 & (1.7) & 43.0 & (2.5) & 58.1 & (1.5) \\
\hline Chicharrón & 54.6 & $(0.6)$ & 57.1 & (2.6) & 56.1 & (3.5) & 91.0 & (5.4) & 30.0 & (1.8) & 58.0 & (1.8) & 70.0 & (0.9) \\
\hline Hummus & 55.5 & (1.6) & 60.0 & (1.7) & 52.0 & (2.5) & 84.0 & $(2.8)$ & 31.0 & $(0.8)$ & 62.0 & (2.5) & 68.0 & (1.5) \\
\hline Queso & 48.7 & $(0.5)$ & 63.0 & (2.1) & 58.0 & (2.6) & 78.0 & (4.7) & 29.0 & (1.5) & 31.0 & (1.7) & 69.0 & $(0.7)$ \\
\hline Musgo & 51.7 & $(0.7)$ & 67.0 & $(4.1)$ & 59.0 & (1.5) & 72.0 & (8.6) & 29.5 & $(0.8)$ & 50.0 & (4.3) & 68.0 & (1.5) \\
\hline Erizos & 39.9 & $(0.7)$ & 68.0 & (1.1) & 56.0 & (3.3) & 66.0 & $(0.9)$ & 29.0 & $(0.7)$ & 40.0 & $(0.9)$ & 69.0 & (1.8) \\
\hline Pan & 52.6 & $(0.8)$ & 59.5 & $(0.8)$ & 39.5 & (3.4) & 82.5 & $(2.2)$ & 30.0 & $(0.3)$ & 37.0 & $(0.6)$ & 52.5 & $(4.8)$ \\
\hline Polen & 57.4 & (1.4) & 62.5 & $(0.8)$ & 50.0 & (4.3) & 80.0 & (1.4) & 30.0 & (0.4) & 68.5 & (2.4) & 61.0 & (1.5) \\
\hline Malvasía & 41.5 & (1.1) & 61.0 & $(0.1)$ & 42.0 & $(0.8)$ & 74.0 & (1.6) & 32.0 & $(0.6)$ & 49.0 & (1.7) & 53.0 & (1.7) \\
\hline Gamba & 53.3 & (1.6) & 67.0 & (5.7) & 46.5 & (1.2) & 69.5 & $(0.7)$ & 30.0 & $(2.8)$ & 60.5 & (3.5) & 56.0 & $(0.8)$ \\
\hline Manzanilla & 58.7 & $(0.7)$ & 78.0 & $(0.8)$ & 70.0 & $(0.6)$ & 68.0 & (1.4) & 30.0 & $(2.7)$ & 99.0 & $(0.6)$ & 75.0 & (2.4) \\
\hline Mostaza & 52.1 & (1.6) & 62.0 & $(2.7)$ & 42.5 & (2.4) & 73.0 & (4.9) & 30.0 & $(0.8)$ & 49.5 & (1.4) & 54.0 & (1.1) \\
\hline $\begin{array}{l}\text { Blanco } \\
\text { Alemán }\end{array}$ & 39.8 & $(0.4)$ & 62.0 & $(2.1)$ & 42.5 & (1.4) & 73.0 & $(0.8)$ & 30.0 & (0.6) & 49.5 & $(0.8)$ & 54.0 & $(0.4)$ \\
\hline Blanquet & 64.4 & (1.7) & 62.0 & $(0.1)$ & 42.5 & (2.1) & 74.0 & $(7.1)$ & 29.5 & $(0.7)$ & 32.5 & $(2.1)$ & 50.0 & (1.4) \\
\hline Jerez & 51.7 & $(0.7)$ & 56.0 & $(0.4)$ & 79.0 & $(0.6)$ & 58.0 & $(0.6)$ & 30.0 & (1.6) & 70.0 & (1.4) & 77.0 & $(0.8)$ \\
\hline Mero & 29.0 & $(0.7)$ & 61.0 & (1.4) & 32.0 & (1.2) & 75.5 & (1.6) & 29.0 & (1.4) & 34.5 & $(0.6)$ & 42.5 & $(0.7)$ \\
\hline Rioja Blanco & 51,5 & (1.4) & 63.0 & $(0.7)$ & 28.0 & (1.7) & 58.0 & (2.1) & 32.0 & (1.7) & 23.0 & $(2.1)$ & 27.0 & (1.6) \\
\hline Arroz & 22.0 & (1.0) & 61.0 & (1.4) & 24.0 & $(0.9)$ & 80.0 & (1.6) & 30.0 & $(0.1)$ & 44.0 & $(0.8)$ & 37.5 & $(0.6)$ \\
\hline Penedés & 33.7 & $(0.6)$ & 80.0 & $(2.7)$ & 49.0 & (1.4) & 57.0 & $(2.7)$ & 33.0 & $(2.1)$ & 61.0 & (1.6) & 59.0 & $(0.9)$ \\
\hline Asado & 34.9 & (1.3) & 61.0 & (1.4) & 25.5 & $(0.4)$ & 77.5 & (1.6) & 30.0 & $(0.2)$ & 42.0 & (3.9) & 39.0 & $(2.7)$ \\
\hline Bairrada & 40.6 & $(0.8)$ & 63.0 & $(0.6)$ & 41.0 & (1.6) & 72.0 & $(0.8)$ & 29.0 & $(2.4)$ & 51.0 & (0.6) & 54.0 & $(0.8)$ \\
\hline Chirivía & 28.3 & (1.1) & 63.5 & $(0.7)$ & 24.0 & (1.4) & 73.0 & $(0.8)$ & 30.0 & $(0.1)$ & 40.0 & $(0.7)$ & 34.5 & (3.4) \\
\hline $\begin{array}{l}\text { Dulce } \\
\text { Francés }\end{array}$ & 50.4 & $(2.7)$ & 71.0 & $(0.7)$ & 47.0 & $(0.6)$ & 63.0 & (1.4) & 31.0 & (1.4) & 65.0 & $(0.6)$ & 54.0 & $(0.8)$ \\
\hline Brioche & 50.8 & $(0.8)$ & 65.0 & $(0.1)$ & 39.5 & $(0.9)$ & 72.0 & $(0.7)$ & 30.0 & $(0.1)$ & 56.0 & $(0.1)$ & 50.0 & (5.7) \\
\hline $\begin{array}{l}\text { Moscatel } \\
\text { dulce }\end{array}$ & 48.2 & $(2.1)$ & 70.0 & $(0.6)$ & 60.0 & $(2.1)$ & 69.0 & (1.7) & 33.0 & $(2.1)$ & 45.0 & $(2.1)$ & 62.0 & $(0.6)$ \\
\hline Supermousse & 42.9 & $(0.9)$ & 59.5 & $(2.1)$ & 33.5 & (3.5) & 73.0 & $(0.8)$ & 29.5 & $(0.7)$ & 42.5 & $(0.7)$ & 45.0 & (1.4) \\
\hline Oporto & 38.5 & $(0.6)$ & 86.0 & (1.4) & 45.0 & $(1.4)$ & 62.0 & $(0.4)$ & 32.0 & (0.6) & 59.0 & $(1.7)$ & 45.0 & $(2.4)$ \\
\hline Average & 47.2 & (11.8) & 62.8 & (3.5) & 40.9 & $(12.4)$ & 76.4 & (6.5) & 29.9 & $(0.7)$ & 46.8 & (10.9) & 53.8 & (11.9) \\
\hline
\end{tabular}

After measurements using neuromarketing biometrics were taken, an in-depth interview (semi structured) was conducted. The first phase included open questions (about the experience) and natural recall, and the second phase questions were about suggested recall. 
The questions asked were related to the decoration, the accessories, the service, and the experience in general, apart from the dishes and wines tasted.

The experience, in general, was rated by everyone as memorable and enriching, with a clear memory of the dishes and some wines. Most diners would repeat the experience, highlighting the service, facilities, and food (presentation, ingredients, and flavors). Most of the diners recalled about 15 dishes of the 18 served, proceeding to their correct description. The most remembered were the Blanquet and Mostaza (flavors) as well as the Brioche (interaction). All diners remembered the plating of some dishes (for its originality) such as the Mostaza, Pollen, Gamba, or Arroz. Regarding the serving order of the dishes and wines, the consumers remembered them as Starters group, Main Courses group, and Desserts group.

The opinions regarding the wine pairings were very positive: the wines were very different, with very different flavors and each perfectly complemented the accompanying dish, highlighting its flavors. In addition, the presentations of the wines was very interesting, since they did not limit themselves to explaining the characteristics of the wine, but also provide anecdotes and its history.

The overall experience was rated by the diners as enriching and very good. They commented that the service was excellent, the facilities impeccable, and the food surprising (for the presentation, the ingredients, the way of cooking and the flavors). Some diners highlighted that the length of the experience was a bit long, but the majority would repeat the gourmet experience.

\section{Discussion}

\subsection{Haute Cuisine; the Emotional Impact of Dishes versus Wines on Restaurant Dinners}

The research has a theoretical implication in innovation in the service sector, based on the use of neuromarketing technologies applied to the analysis of consumer behavior. In the service sector, there are two key business models: a model based on product orientation, and a model based on customer orientation. Both are implemented with product innovation [83]. The interaction between innovation in services and products generates long-term benefits. If this does not occur, short-term gains can be made, limiting long-term performance.

In the gastronomic sector, the concept of innovation is growing, because it is a competitive and demanding sector [84]. The purpose of this document is to discover the level of emotional influence of the stimuli offered to consumers in a haute cuisine gastronomic experience. From the food and marketing literature, a conceptual framework was developed and tested using data from 30 sampled consumers. The data were generated using neuromarketing biometrics and were analyzed in order to identify those stimuli with the highest arousal.

In order to improve the consumer experience and interaction with the customer, innovative solutions are required that improve commercial efficiency and profitability [85].

This research focused on the innovation of services in the gastronomic sector from the perspective of consumers. The company should create a customer-oriented innovation driving force and select the corresponding types of innovation, creating common values with consumers [86].

In turn, this research has a practical implication in innovation in the service sector by empirically demonstrating the positive effects of the commercial interaction with the client, in the face of the service offered.

The study analyzed, in haute cuisine restoration, the intersection between sensory and experiential marketing and consumer behavior [87], with the aim of distinguishing and comparing the consumers' perception of presentation and tasting of dishes and wines, satisfying the needs of consumers and haute cuisine [88]. Neuromarketing allows us to efficiently obtain accurate results as well as knowledge, objectivity, and precision of the information, which is very useful in this area [89]. One of the aims of the study was to 
compare and analyze the differences between presentation (experience expectation) and tasting (experience reality) in consumers.

It is worth highlighting that from the biometry application (neuromarketing analysis), according to the GSR (galvanic skin response) records, the dish experience value was higher than the wine experience value (overall value, Figure 8 ) by $4.35 \%$. The presentation phase for dishes and wines registered values similar or higher than the tasting phase, confirming that there is a correlation between taste and the additional information the consumers have at their disposal [73], with a clear influence on the consumers' expectations.

The shape of the special plating dishes was more attractive [90] than the conventional dishes. The appreciation of the consumers of the dishes with special plating [91] permits a comparison of the level of arousal. The emotional intensity level was $2.12 \%$ higher for the dishes with special plating.

The level of arousal decreased throughout the experience [92] to $21.43 \%$ as well as the interaction with the dishes [93] after the experience passed the midway point. The breakdown of the emotional level into three groups allowed us to observe that the Starters obtained better GSR valuations (average of 0.51), compared to Main Courses group, and Desserts group (arousal values of 0.41 and 0.43 , respectively).

According to brain electrical activity records (EEG values) [94], the average values of interest, focus, engagement, and excitement were higher (in that order) for dishes and wines. Relaxation had low values during the whole experience. All averages of the EEG variables were higher for wines than for dishes, except for interest, which was higher for dishes [95]. The GSR values reflected that dishes elicited a more emotional response than wines.

According to the information obtained from eye tracking biometrics [96], the common denominator during the experience was that the consumer alternated attention between the chef and the dish (or sommelier and the glass) during the presentation phase, although the dish was contemplated more times (for the most striking ones). The consumer mainly focused on the dish (during the tasting of the dishes), especially on those in which the dish interacted. This consumer behavior changed for wines, due to the fact that during the presentation of wine, their attention was longer for the sommelier than for the glass.

From traditional marketing (in-depth interview), it can be highlighted that the satisfied diners considered the experience very good and enriching, and that their expectations were met [97], so they were delighted [98].

The influence of the chef's personal brand, the restaurant's name, and the influence of repeating the experience were the limitations considered in this research.

\subsection{Haute Cuisine and Open Innovation in Restaurant Industry}

The innovation system of the food industry is based both on the company and on the rest of the entities involved, with regard to decisions and activities [99]. Due to the large number of actors involved, innovation activities have to be coordinated, in order to develop innovative products in an open innovation mechanism. Open innovation strategies must be meaningful and based on both access to external sources of knowledge and its creation. There are studies that highlight how companies in the food industry have been able to overcome innovation barriers.

Open innovation in the food industry is in a growth phase, having to face problems of the integration of the concept in the innovation management process. There is a growing interest of these companies in opening their innovation processes [100], obtaining benefits from collaboration with universities and other sources of knowledge.

The main characteristics of the current food industry refer to the increasing number of actors in the food chain and the heterogeneous needs of consumers. Consequently, open innovation should be considered a generalized corporate practice.

Difficulties in meeting the heterogeneous needs of customers, end-users, and legislators is driving the food industry to open up to external sources of knowledge in search of new successful products and technologies [101]. However, the number of companies par- 
ticipating in open innovation is scarce. Even though the food industry is more traditional and mature, open innovation strategies come in a variety of forms and as such, also meet a wide variety of outcomes.

Within the food industry, open innovation plays an important role in restaurant success. This allows for a rational strategy for a small restaurant to attract and retain customers, being essential for the success of small restaurants [14]. If a small restaurant adopts a closed innovation strategy, whether in ingredients, recipes, or food service, it must choose an open innovation strategy to maintain its competitive advantage compared to others. An open innovation ecosystem for ingredients, recipes, or food services can generate additional income through the sale of independent ingredients or services. There is literature on key cases of restaurant ecosystems [102], where an open innovation framework was used to analyzed how to grow. Building a successful business ecosystem that shares knowledge, encourages individual growth, and embeds trust among participants generates sustained growth models, expanding "open innovation" with stakeholders such as suppliers, chef alumni, and staff, food writers, and others.

\section{Conclusions}

This study raises a main objective based on the use of neuromarketing technology for the analysis of emotions in a gastronomic experience in a two Michelin star restaurant (tasting of dishes and wines). The use of quantitative research techniques and neuromarketing knowledge allows for an analysis of the global experience of presenting and tasting dishes and wines.

The main contribution presented in this research has been the identification of the emotional level of the dishes and wines in a haute cuisine experience, analyzing the influence of the presentation compared to the tasting, based on the arousal metrics of the consumers. This allows for a better understanding of the results in the levels of arousal (emotional intensity) of the diner originated by the dishes and the wines, identifying the most valued aspects in gastronomic experience consumption, considered key in an open innovation process.

This original research analyzed the cognitive and emotional activities (from the neuromarketing perspective) of the diners tasting gastronomic products. The results can be used to understand the emotional components of the purchasing process and presentation of dishes and wines as having a storytelling influence on purchase [72]. Emotional control aims to regulate the experience of stimuli [103].

Finally, innovation in the haute cuisine sector using neuromarketing techniques revealed that knowledge of the mental states of the consumers (conscious and unconscious) allows for more efficient commercial strategies. Technology from the neurosciences applied to the service sector allows for the identification of stimuli that influence the brain (deeper knowledge), consumer behavior, and decision making [104].

Author Contributions: Conceptualization, V.T.-V. and D.J.-V.; Methodology, V.T.-V.; Software, A.M.-R.; Validation, V.T.-V., A.M.-R., and D.J.-V., Formal analysis, A.M.-R. and F.A.-V.; Investigation, A.M.-R.; Resources, D.J.-V.; Data curation, A.M.-R.; Writing—original draft preparation, A.M.-R. Writingreview and editing, V.T.-V. and A.M.-R.; Visualization, F.A.-V.; Supervision, D.J.-V.; Project administration, V.T.-V. and D.J.-V. All authors have read and agreed to the published version of the manuscript.

Funding: No specific grant from funding agencies in the public, commercial, or not-for-profit sectors was received.

Data Availability Statement: The raw data supporting the conclusions of this article will be made available by the authors, without undue reservation.

Conflicts of Interest: The authors declare no conflict of interest.

Ethics Statement: This study was approved by the Universitat Politècnica de València (UPV) Research Ethics Committee. Subjects were informed and gave their written informed consent for their voluntary participation and anonymous contribution. 


\section{References}

1. Hipp, C.; Grupp, H. Innovation in the service sector: The demand for service-specific innovation measurement concepts and typologies. Res. Policy 2005, 34, 517-535. [CrossRef]

2. Chesbrough, H.; Vanhaverbeke, W.; West, J. Open Innovation: Researching a New Paradigm; Oxford University Press on Demand: Oxford, UK, 2006.

3. Chesbrough, H.W. Open Innovation: The New Imperative for Creating and Profiting from Technology; Harvard Business School Press: Boston, MA, USA, 2003.

4. Chesbrough, H.; Bogers, M. Forthcoming, Explicating open innovation: Clarifying an emerging paradigm for understanding innovation. In New Frontiers in Open Innovation; Oxford University Press: Oxford, UK, 2014; pp. 3-28. [CrossRef]

5. West, J.; Salter, A.; Vanhaverbeke, W.; Chesbrough, H. Open innovation: The next decade. Res. Policy 2014, 43, 805-811. [CrossRef]

6. Hervas-Oliver, J.-L.; Sempere-Ripoll, F.; Boronat-Moll, C. Technological innovation typologies and open innovation in SMEs: Beyond internal and external sources of knowledge. Technol. Forecast. Soc. Chang. 2021, 162, 120338. [CrossRef]

7. Tirmizi, S.M.A.; Malik, Q.A.; Hussain, S.S. Invention and Open Innovation Processes and Linkages: A Conceptual Framework. J. Open Innov. Technol. Mark. Complex. 2020, 6, 159. [CrossRef]

8. Bogers, M.; Chesbrough, H.; Strand, R. Sustainable open innovation to address a grand challenge: Lessons from Carlsberg and the Green Fiber Bottle. Br. Food J. 2020, 122, 1505-1517. [CrossRef]

9. Buera, F.; Kaboski, J. The Rise of the Service Economy. Rise Serv. Econ. 2009, 102, 2540-2569.

10. Rubalcaba, L.; Gago, D.; Maroto, A. Relationships between globalization and services: Competitive advantages of European and Spanish services in international trade. Inf. Comer. Esp. -Mon. Ed. 2005, 824, 93.

11. Porter, M.E. Competitive Advantage of Nations: Creating and Sustaining Superior Performance; Simon and Schuster: New York, NY, USA, 2011.

12. Sheehan, J. Understanding service sector innovation. Commun. ACM 2006, 49, 42-47. [CrossRef]

13. Nam, K.W.; Kim, B.Y.; Carnie, B.W. Service Open Innovation; Design Elements for the Food and Beverage Service Business. J. Open Innov. Technol. Mark. Complex. 2018, 4, 53. [CrossRef]

14. Yun, J.J.; Park, K.; Del Gaudio, G.; Della Corte, V. Open innovation ecosystems of restaurants: Geographical economics of successful restaurants from three cities. Eur. Plan. Stud. 2020, 28, 2348-2367. [CrossRef]

15. Bunghez, C.L. The importance of tourism to a destination's economy. J. East. Eur. Res. Bus. Econ. 2016, 2016, 1-9. [CrossRef]

16. Guerrero-Sánchez, D.L. El impacto de la capacidad de absorción potencial del conocimiento sobre la innovación en marketing. Contaduría Adm. 2021, 66, 1-25. [CrossRef]

17. Bertoch, M. Prospects for the Restoration in Europe for 2018 (Perspectivas de la Restauración en Europa Para 2018); The NPD Group: New York, NY, USA, 2018.

18. Restaurants, T.W.B. The Worlds 50 Best Restaurants; William Reed Business Media Ltd.: Crawley, UK, 2018. Available online: https:/ / www.theworlds50best.com/ (accessed on 24 November 2018).

19. Mengual-Recuerda, A.; Tur-Viñes, V.; Varón, D.J. Neuromarketing in Haute Cuisine Gastronomic Experiences. Front. Psychol. 2020, 11, 1772. [CrossRef]

20. Kim, E.; Nicolau, J.L.; Tang, L. (Rebecca) The Impact of Restaurant Innovativeness on Consumer Loyalty: The Mediating Role of Perceived Quality. J. Hosp. Tour. Res. 2021. [CrossRef]

21. Romero, I.; Gómez, I.P.; Zabala-Iturriagagoitia, J.M. 'Cookpetition': Do restaurants coopete to innovate? Tour. Econ. 2019, 25, 904-922. [CrossRef]

22. Presenza, A.; Abbate, T.; Sánchez, A.V.; Harrison, T. Creativity and innovation: The case of haute cuisine. Int. J. Entrep. Innov. Manag. 2018, 22, 562. [CrossRef]

23. Tan, T.F.; Netessine, S. At your service on the table: Impact of tabletop technology on restaurant performance. Manag. Sci. 2020, 66, 4496-4515. [CrossRef]

24. Blöcher, K.; Alt, R. AI and robotics in the European restaurant sector: Assessing potentials for process innovation in a high-contact service industry. Electron. Mark. 2020, 1-23. [CrossRef]

25. Schwark, N.; Tiberius, V.; Fabro, M. How Will We Dine? Prospective Shifts in International Haute Cuisine and Innovation beyond Kitchen and Plate. Foods 2020, 9, 1369. [CrossRef]

26. Moreno, M. El Marketing Experiencial en la Cocina; Branward S.L.: Barcelona, Spain, 2015.

27. Lawrence, T.B.; Phillips, N. Understanding cultural industries. J. Manag. Inq. 2002, 11, 430-441. [CrossRef]

28. Simatupang, T.M.; Schwab, A.; Lantu, D. Introduction: Building Sustainable Entrepreneurship Ecosystems. SSRN Electron. J. 2015, 26, 389-398. [CrossRef]

29. Meneguel, C.R.D.A.; Mundet, L.; Aulet, S. The role of a high-quality restaurant in stimulating the creation and development of gastronomy tourism. Int. J. Hosp. Manag. 2019, 83, 220-228. [CrossRef]

30. Michelin Guides Worlwide. 2019. Available online: https://guide.michelin.com/en/michelin-guides-worldwide (accessed on 10 April 2019).

31. Cancela, A. Michelin Guide Collection (Colección Guías Michelin); A. Cancela \& J. Cancela: Coruna, Spain, 2020; Available online: https: / / www.cancela.org/ (accessed on 20 June 2020).

32. Cambio16. Cambio16. 2017. Available online: www.cambio16.com (accessed on 18 June 2020).

33. Armitage, J. Luxury and Visual Culture; Zed Books Ltd.: London, UK, 2019. 
34. Santos, C. The Influence of Advertising on Youth Consumption of Clothing and Footwear Brands: A case study. Int. J. Mark. Commun. 2016, 4, 85-105.

35. Lučić, A.; Dabić, M.; Finley, J. Marketing innovation and up-and-coming product and process innovation. Int. J. Entrep. Small Bus. 2019, 37, 434-448. [CrossRef]

36. Dixon, S.-M.; Shankar, A. Footwear with feeling: A cultural approach to product development. J. Mark. Manag. 2018, 34, 536-537. [CrossRef]

37. Fugate, D.L. Marketing services more effectively with neuromarketing research: A look into the future. J. Serv. Mark. 2008, 22, 170-173. [CrossRef]

38. Hammou, K.A.; Galib, H.; Melloul, J. The Contributions of Neuromarketing in Marketing Research. J. Manag. Res. 2013, 5, 20. [CrossRef]

39. Glimcher, P.W.; Camerer, C.F.; Fehr, E.; Poldrack, R.A. (Eds.) Chapter 1-Introduction: A Brief History of Neuroeconomics; Academic Press: London, UK, 2009; pp. 1-12.

40. Crone, E.A.; Ridderinkhof, K.R. The developing brain: From theory to neuroimaging and back. Dev. Cogn. Neurosci. 2011, 1, 101-109. [CrossRef]

41. Morin, A.J.; Scalas, L.F.; Vispoel, W.; Marsh, H.W.; Wen, Z. The Music Self-Perception Inventory: Development of a short form. Psychol. Music. 2016, 44, 915-934. [CrossRef]

42. Lăzăroiu, G.; Pera, A.; Ștefănescu-Mihăilă, R.O.; Mircică, N.; Negurită, O. Can Neuroscience Assist Us in Constructing Better Patterns of Economic Decision-Making? Front. Behav. Neurosci. 2017, 11, 188. [CrossRef] [PubMed]

43. Vecchiato, R.; Roveda, C. Strategic foresight in corporate organizations: Handling the effect and response uncertainty of technology and social drivers of change. Technol. Forecast. Soc. Chang. 2010, 77, 1527-1539. [CrossRef]

44. Thomas, J.M.; Liu, J.; Robinson, E.L.; Aveyard, P.; Herman, C.P.; Higgs, S. The Effects of Liking Norms and Descriptive Norms on Vegetable Consumption: A Randomized Experiment. Front. Psychol. 2016, 7, 442. [CrossRef] [PubMed]

45. Velasco, C.; Wan, X.; Knoeferle, K.; Zhou, X.; Salgado-Montejo, A.; Spence, C. Searching for flavor labels in food products: The influence of color-flavor congruence and association strength. Front. Psychol. 2015, 6, 301. [CrossRef]

46. Fehse, K.; Simmank, F.; Gutyrchik, E.; Sztrókay-Gaul, A. Organic or popular brands-food perception engages distinct functional pathways. An fMRI study. Cogent Psychol. 2017, 4, 1284392. [CrossRef]

47. Biswas, D.; Szocs, C.; Chacko, R.; Wansink, B. Shining Light on Atmospherics: How Ambient Light Influences Food Choices. J. Mark. Res. 2017, 54, 111-123. [CrossRef]

48. Plassmann, H.; Ramsøy, T.Z.; Milosavljevic, M. Branding the brain: A critical review and outlook. J. Consum. Psychol. 2012, 22, 18-36. [CrossRef]

49. Madan, C.R. Neuromarketing: The next step in market research? Eureka 2010, 1, 34-42. [CrossRef]

50. Zajonc, R.B. Feeling and thinking: Preferences need no inferences. Am. Psychol. 1980, 35, 151-175. [CrossRef]

51. Juárez-Varón, D.; Tur-Viñes, V.; Rabasa-Dolado, A.; Polotskaya, K. An Adaptive Machine Learning Methodology Applied to Neuromarketing Analysis: Prediction of Consumer Behaviour Regarding the Key Elements of the Packaging Design of an Educational Toy. Soc. Sci. 2020, 9, 1-23. [CrossRef]

52. Baron, A.S.; Zaltman, G.; Olson, J. Barriers to advancing the science and practice of marketing. J. Mark. Manag. 2017, 33, 893-908. [CrossRef]

53. Ariely, D.; Berns, G.S. Neuromarketing: The hope and hype of neuroimaging in business. Nat. Rev. Neurosci. 2010, 11, 284-292. [CrossRef] [PubMed]

54. Torreblanca, F.; Juarez, D.; Sempere, F.; Mengual, A. Neuromarketing: Emotionality and creativity oriented to consumer behavior. 3C Empresa 2012, 1, 1-11. Available online: https:/ / www.3ciencias.com/wp-content/uploads/2012/09/2.neuromarketing.pdf (accessed on 18 June 2020).

55. Hsu, M. Neuromarketing: Inside the Mind of the Consumer. Calif. Manag. Rev. 2017, 59, 5-22. [CrossRef]

56. Molchanov, N.N.; Muraveve, O.; Galay, N.; Korableva, O.N. Neuromarketing as an Innovative Approach to Market Research of Consumer Behavior. In Proceedings of the 29th International Business Information Management Association ConferenceEducation Excellence and Innovation Management through Vision 2020: From Regional Development Sustainability to Global Economic Growth, Vienna, Austria, 3-4 May 2017; Soliman, K.S., Ed.; pp. 2489-2499.

57. Thaler, R.H. From Homo Economicus to Homo Sapiens. J. Econ. Perspect. 2000, 14, 133-141. [CrossRef]

58. Kahneman, D. Thinking, Fast and Slow; Farrar, Straus and Giroux: New York, NY, USA, 2011.

59. Mackie, D.M.; Worth, L.T. Processing deficits and the mediation of positive affect in persuasion. J. Personal. Soc. Psychol. 1989, 57, 27-40. [CrossRef]

60. Filser, M. Marketing sensoriel: La quête de l'intégration théorique et managériale. Rev. Française du Mark. 2003, 194, 5-12.

61. Manzano, R. Sensory Marketing: Communicate with the Senses at the Point of Sale: (Marketing Sensorial: Comunicar con los Sentidos en el Punto de Venta); Pearson: London, UK, 2011.

62. Daucé, B.; Rieunier, S. Le marketing sensoriel du point de vente. Rech. et Appl. en Mark. French Ed. 2002, 17, 45-65. [CrossRef]

63. Krishna, A. (Ed.) Sensory Marketing: Research on the Sensuality of Products; Routledge: London, UK, 2011; pp. 1-13.

64. Li, Q.; Wang, X. A Study on the Influence of Engagement Marketing Strategy on Customer Perceived Support and Willingness to Customer Engagement. In Proceedings of the 2017 IEEE 14th International Conference on e-Business Engineering (ICEBE), Shanghai, China, 4-6 November 2017; pp. 166-171. 
65. Smith, A. The Theory of Moral Sentiments; Penguin: London, UK, 2010.

66. Wilson, T.D.; Gilbert, D.T.; Centerbar, D.B. Making sense: The causes of emotional evanescence. Psychol. Econ. Decis. 2003, 1, 209-233.

67. Oatley, K. Brain Mechanisms and Motivation. Nat. Cell Biol. 1970, 225, 797-801. [CrossRef]

68. VanItallie, T.B. Sleep and energy balance: Interactive homeostatic systems. Metabolism 2006, 55, S30-S35. [CrossRef]

69. Stasi, A.; Songa, G.; Mauri, M.; Ciceri, A.; Diotallevi, F.; Nardone, G.; Russo, V. Neuromarketing empirical approaches and food choice: A systematic review. Food Res. Int. 2018, 108, 650-664. [CrossRef] [PubMed]

70. Stoica, I.; Popescu, M.; Orzan, M. Consumer preferences for organic food. A case study of neuromarketing methods and tools. J. Environ. Prot. Ecol. 2015, 16, 1142-1148.

71. Velasco, C.; Obrist, M.; Petit, O.; Spence, C. Multisensory Technology for Flavor Augmentation: A Mini Review. Front. Psychol. 2018, 9, 8. [CrossRef] [PubMed]

72. Sturiale, L.; Scuderi, A. Interaction between the Emotional and Rational Aspects in Consumer Buying Process for Typical Food Products of Italy. Adv. Bus. Strategy Compet. Advant. 2017, 142-162. [CrossRef]

73. Rybanska, J.; Nagyova, L.; Kubelakova, A. Sensory marketing strategy: Use of the sense of taste on the global market of food. Globalization and Its Socio-Economic Consequences. In Proceedings of the 16th International Scientific Conference Proceedings, Rajecke Teplice, Slovak Republic, 5-6 October 2016; Pts, I.-V., Kliestik, T., Eds.; pp. 1912-1918.

74. Bornstein, R.F.; D'agostino, P.R. Stimulus recognition and the mere exposure effect. J. Personal. Soc. Psychol. 1992, 63, 545. [CrossRef]

75. Ramele, R.; Julia, V.; Miguel, S. EPOC Emotiv EEG Basics; ResearchGate GmbH: Berlin, Germany, 2012; Available online: https: //www.researchgate.net/publication/332514530_EPOC_Emotiv_EEG_Basics\#fullTextFileContent (accessed on 18 June 2020).

76. Sanei, S.; Chambers, J. EEG Signal Processing; John Wiley \& Sons, Inc.: Hoboken, NJ, USA, 2007.

77. Varón, D.J.; Tur-Viñes, V.; Recuerda, A.M. Análisis del diseño de packaging de juguete educativo, mediante neuromarketing. Cuad. Latinoam. Adm. 2019, 15, 1-25. [CrossRef]

78. Emotiv. Emotiv. 2021. Available online: www.emotiv.com (accessed on 25 February 2021).

79. Shimmer. Shimmer Sensing. 2021. Available online: https://www.shimmersensing.com/products/shimmer3-wireless-gsrsensor (accessed on 25 February 2021).

80. Gazepoint. Gazepoint. 2021. Available online: http://gazepoint.com/ (accessed on 25 February 2021).

81. Juárez Varón, D.; Viñes, V.T.; Recuerda, A.M. Neuromarketing Applied to Educational Toy Packaging. Front. Psychol. 2020, 11, 2077. [CrossRef] [PubMed]

82. Añaños-Carrasco, E. Eyetracker technology in elderly people: How integrated television content is paid attention to and processed. Comunicar 2015, 23, 75-83. [CrossRef]

83. Visnjic, I.; Wiengarten, F.; Neely, A.D. Only the Brave: Product Innovation, Service Business Model Innovation, and Their Impact on Performance. J. Prod. Innov. Manag. 2016, 33, 36-52. [CrossRef]

84. Yusheng, K.; Ibrahim, M. Service innovation, service delivery and customer satisfaction and loyalty in the banking sector of Ghana. Int. J. Bank Mark. 2019, 37, 1215-1233. [CrossRef]

85. Chen, C.-L. Service providers' sustainable service innovation: Service-dominant logic. Serv. Ind. J. 2017, 37, 628-656. [CrossRef]

86. Jin, H.Y.; Fei, Y.; Ji, K.M. A Study of the Relations among Driving Force of Service Innovation, Service Innovation Types and Consumer Satisfaction of Service Enterprise: Focusing on Chinese Hotel Industry. Korean Bus. Educ. Rev. 2019, 34, 91-113. [CrossRef]

87. Cerea, E.; Rurale, A. Haute Cousine System and Its Cultural Dimension: When Chefs Are the New Artists. University of Philadelphia Press: Pennsylvania, PA, USA, 2010. Available online: https:/ / papers.ssrn.com/sol3/papers.cfm?abstract_id=1692 084 (accessed on 18 June 2020).

88. Olders, P. Acquired taste or acquired knowledge? Experience, talent and popularity in creating French superstar Cuisine. In Proceedings of the DRUID Society Conference, Copenhagen, Denmark, 16-18 June 2014.

89. Ohme, R.; Matukin, M.; Pacula-Lesniak, B. Biometric Measures for Interactive Advertising Research. J. Interact. Advert. 2011, 11, 60-72. [CrossRef]

90. Bloch, P.H. Seeking the ideal form: Product design and consumer response. J. Mark. 1995, 59, 16-29. [CrossRef]

91. Ungureanu, F.; Lupu, R.G.; Cadar, A.; Prodan, A. Neuromarketing and Visual Attention Study Using Eye Tracking Techniques. In Proceedings of the 2017 21st International Conference on System Theory, Control and Computing, Sinaia, Romania, 19-21 October 2017; Kloetzer, M., Ferariu, L., Eds.; pp. 553-557.

92. Parker, P.M.; Tavassoli, N.T. Homeostasis and consumer behavior across cultures. Int. J. Res. Mark. 2000, 17, 33-53. [CrossRef]

93. Sterner, R. Modelling interactions of food quality and quantity in homeostatic consumers. Freshw. Biol. 1997, 38, 473-481. [CrossRef]

94. Fakhruzzaman, M.N.; Riksakomara, E.; Suryotrisongko, H. EEG Wave Identification in Human Brain with Emotiv EPOC for Motor Imagery. Procedia Comput. Sci. 2015, 72, 269-276. [CrossRef]

95. Carvalho, F.R.; Moors, P.; Wagemans, J.; Spence, C. The Influence of Color on the Consumer's Experience of Beer. Front. Psychol. 2017, 8, 2205. [CrossRef] [PubMed]

96. Duchowski, A.T. Eye Tracking Methodology: Theory and Practice; Springer International Publishing: Berlin/Heidelberg, Germany, 2003; Volume 328, pp. 2-3. 
97. Ran, Y.; Wei, H.; Li, Q. Forgiveness from Emotion Fit: Emotional Frame, Consumer Emotion, and Feeling-Right in Consumer Decision to Forgive. Front. Psychol. 2016, 7, 1775. [CrossRef] [PubMed]

98. Kim, W.; Kim, B. Consumption Motivation of Limited Edition Product in Reselling Open Market. J. Open Innov. Technol. Mark. Complex. 2020, 6, 133. [CrossRef]

99. Bigliardi, B.; Galati, F. Models of adoption of open innovation within the food industry. Trends Food Sci. Technol. 2013, 30, 16-26. [CrossRef]

100. Chesbrough, H.W. The era of open innovation. Manag. Innov. Chang. 2006, 127, 34-41.

101. Sarkar, S.; Costa, A. Dynamics of open innovation in the food industry. Trends Food Sci. Technol. 2008, 19, 574-580. [CrossRef]

102. Chesbrough, H.; Kim, S.; Agogino, A. Chez Panisse: Building an Open Innovation Ecosystem. Calif. Manag. Rev. 2014, 56, 144-171. [CrossRef]

103. Gross, J.J.; Thompson, R.A. Emotion regulation: Conceptual foundations. In Handbook of Emotion Regulation; Gross, J.J., Ed.; Guilford Press: New York, NY, USA, 2007; pp. 3-24.

104. Morin, C. Neuromarketing: The New Science of Consumer Behavior. Society 2011, 48, 131-135. [CrossRef] 